physical significance. Of such stars there ought to be about 281,250 , and at the present rate of progress the determination of their parallaxes would occupy astronomy for fully 1000 years to come.

Just now we compared astronomy's past 3000 years of existence to the last tick of the clock in a dying century; we may with equal justice compare the 3000 years next to come to the first tick in a new century-such is the proportion it bears to the total time our present stars may be expected to last. Looked at on this scale there may be thought to be plenty of time for a really exhaustive survey of the universe, and past progress may be accounted amazingly rapid. In one tick of the clock astronomy has come to birth, has developed the most difficult and accurate technique known to science, and has surveyed the universe, accurately and completely to 4 parsecs, and sketchily and imperfectly beyond. The next tick of the clock should see the accurate survey extended to well beyond 100 parsecs, and astronomy has a whole century of life before it. I fear there may be a fallacy involved in the adoption of this point of view ; it is that we do not know how long the human race will endure. At the very longest estimate, man has only existed for a hundred ticks of our clock, civilised man for only two or three, so that our race and civilisation would alike seem to be at the very beginning of their existence. Yet he would be a bold extrapolator who would assert with confidence that man is good for another three thousand million ticks of our clock on the ground that, if nothing unforeseen happens, the present stars will still be in existence at the end of that time. When we take a time-scale in terms of individual lives, we may still feel gratified at past progress, yet we cannot but feel awed by the magnitude of the task that remains.

\title{
On Rejuvenation.
}

REW human beings will view the approach of old age with philosophic calm, so that any method by which the period of maturity may be prolonged and the onset of senility delayed will always arouse widespread interest and discussion. Within the last few years a considerable amount of attention has been directed to the subject of rejuvenation, following certain somewhat sensational operations on human beings and the higher apes. Although there is no doubt that the internal secretions of the genital glands exert a pronounced effect upon the rest of the body, yet it is by no means certain that old age can be attributed solely to their degeneration : in fact, the cells of the body as a whole suffer decay, so that it is probable that an operation affecting only one of the organs of the body, only one, moreover, of the number which influence the activities of the other cells throughout life, would have no more than a temporary effect at best.

Although removal of the genital glands has a profound influence upon the mentality and bodily structure of the subject, yet evidence as to its effects upon strength and endurance has been conflicting. M. D. Sumulong, in a recent paper (Philippine Jour. Sci., Mar. 1926, p. 327), from experiments on guinea-pigs, concludes that castration is without definite influence upon their pulling power or endurance. Yet one of the characteristic results of a rejuvenating operation has been the increased physical vigour of the subject, suggesting again that decay of the genital glands is not the sole factor in old age. Finally, in discussing the results of human experiments, it is difficult to know how far the element of suggestion must be taken into consideration.

Various operations have been proposed for rejuvenating purposes; thus transplantation of the gland from another individual of the same, or a closely allied, species has been effective, especially in the female. In the male, the ligation of the efferent duct from the testicular gland has been advocated as a much simpler, withal as effective, a procedure. It is of interest to note that the flatworm Planaria can be rejuvenated by starvation. It shrinks to one-quarter its adult size and becomes young again: if fed, it grows up: the process can be repeated indefinitely and the organism's life may be prolonged to twenty times the ordinary length (F. A. E. Crew, Nineteenth Century, Feb. 1927, p. 225). The infinitely more complex structure of the higher animals, however, prevents the recourse to such a simple expedient.

The justification for the operation of ligature of the efferent duct of the testes, or vasoligation as it is called, depends on the assumption that this procedure causes degeneration of the sex cells proper, thus permitting the interstitial cells to hypertrophy, with a consequent increase in the amount of the internal secretion produced by them. It might not even be necessary for them to hypertrophy: with degeneration of the sex cells the nutriment supplied to the whole gland by the blood stream might be sufficient for the full activity of the internal secretory cells, whereas with the sex cells present the former might fail to obtain all the food they required owing to the competition of the latter. In the period of full maturity both types of cells are probably sufficiently supplied by an efficient circulation.

Oslund has stated that vasoligation does not lead to degeneration of the sex cells unless the testis moves from its usual position in the scrotum into the abdomen. Y. Tamura and F. A. E. Crew, in experiments on the mouse (Proc. Roy. Soc. Edin., 1926, vol. 46, p. 283), find that this operation is followed by degeneration of the sex cells, provided sufficient time has elapsed before the testis is examined. If the epididymis is removed, degeneration occurs much earlier. On the other hand, in neither case was the degeneration complete. The evidence, however, favours the assumption on which the operation of vasoligation is based.

From what has been said above, it is clear that the two functions of the testis are to a certain

No. 2993, VoL. 119] 
extent independent. Thus an individual may be rejuvenated, without at the same time becoming capable of begetting offspring. This would naturally occur if vasoligation was performed on both sides. The unilateral operation, or gland transplantation, on the other hand, might lead to renewed activity in the individual's own glands, with the production of spermatozoa and a further period of fertility.

In the female, apart from gland transplantation, which may lead to renewed activity in the individual's own ovaries, the sex cells may be destroyed by irradiation with the X-rays; in the latter case rejuvenation, due to increased activity of the interstitial cells of the ovary, is of course accompanied by sterility.

One other possible method of the future may be mentioned, and that is rejuvenation by the ad- ministration of potent extracts from the sex-glands. In the case of the female, the hormone which produces 'heat can be extracted in a, probably crude, condition from the ovaries of a number of animals and is effective on subcutaneous injection. No such active extract has yet been obtained from the testis. At any rate, the effect of the former upon the general bodily condition has not yet been studied.

By some one of these methods, used in time, it may become possible to prolong the span of life. In the case of the rat, death has been postponed for a period equal to one-fourth its average length of life. No information is available in the case of man, but it is claimed, as Crew points out, that senility in a rejuvenated individual is sudden, and death, when this phase of life is reached, soon supervenes.

\section{Obituary.}

Colonel C. H. T. Marshall.

Got. OL. CHARLES HENRY TILSON MARSHALL died in London on Jan. 20 in his eighty-sixth year. He was born on July 8, 1841, and was the eldest son of W. Knox Marshall of Hereford. He entered the Indian Army in 1859, and on arrival in India was attached to the 35th Royal Sussex Regiment. On leaving this regiment he joined the 3rd Sikhs, Punjab Frontier Force, but saw little military service, being appointed in 1865 to the Punjab Commission. After filling various appoint. ments with exceptional ability, he was finally made Assistant Commissioner of Lahore, retiring in 1896.

Col. Marshall was best known to Indian and other ornithologists not so much as a scientific worker but as a field naturalist. Wherever he was posted, and his districts were many, he made copious observations and notes on the local birds, and it was his extensive knowledge of game birds and his high reputation as a small-game shot that induced Hume to obtain his collaboration in the "Game Birds of India" in 1879. The three volumes composing this work are full of Marshall's field notes, and the business portion of the work, such as arrangement of plates, etc., also fell to his share. Marshall was, however, never fond of publishing his vast stores of bird lore, and never brought out any book in his own name alone for the benefit of his brother workers. At the same time, "Stray Feathers," Hume's journal of ornithology, which ran through eleven volumes, contains many of his notes, which also appeared from time to time in other Indian papers and journals. In 1877 his brother, then Capt. G. F. L. Marshall, R.E., brought out a book entitled "Bird Nesting in India," and in this volume much of the valuable information compiled was obtained from Col. Marshall. They were also associated in bringing out "The Monograph of the Capitonidæ or Scansorial Barbets," 1870. Their name has since been given to one of the most beautiful of Indian barbets, Megaloema marshallorum.

After his retirement in 1896 Col. Marshall returned to England, and since that date, with the exception of a few articles in English papers, he ceased to write upon ornithology. His brother, General Marshall, who survives him, is, of course, well known to ornithologists and botanists not only in India but also elsewhere. His son, Dr. G. A. K. Marshall, is now Director of the Imperial Bureau of Entomology.

WE regret to record the death on Feb. 18, at Oxford, in his seventy-fifth year, of Mr. Frederick Eden Pargiter, the well-known oriental scholar. Mr. Pargiter was educated at Taunton Grammar School and Exeter College, Oxford, where he took a first class in both Moderations and the final schools. He was also Boden Sanskrit scholar. He entered the Indian Civil Service in 1876 and served as district and sessions judge and was a judge of the Calcutta High Court, retiring in 1906. He was an active member of the Asiatic Society of Bengal, of which he was successively secretary and president. On his retirement, he became closely associated with the work of the Royal Asiatic Society, serving for some years on its council and later becoming one of its vice-presidents. In his oriental studies he showed great originality. His "Dynasties of the Kali Age," published in 1913, was a work which initiated the critical study of the semihistorical, semi-legendary Puranas. This study he carried further in his annotated translation of the Markandeya Purana and "Ancient Historic Indian Tradition." He was a frequent contributor to Epigraphia Indica and prepared for the press the centenary volume of the Royal Asiatic Society issued in 1923.

WE regret to announce the following deaths :

Dr. A. W. Crossley, F.R.S., who had just resigned the post of Director of the British Cotton Industry Researeh Association, on Mar. 5, aged fifty-eight years.

Dr. Ira Remsen, president emeritus of Johns Hopkins University, Baltimore, who was largely responsible for the organisation of chemical teaching and research in the United States, and was also the author of well-known text-books on chemistry, aged eighty-one years. 